\title{
Regional Assessment of Soybean Brown Stem Rot, Phytophthora sojae, and Heterodera glycines Using Area-Frame Sampling: Prevalence and Effects of Tillage
}

\author{
F. Workneh, G. L. Tylka, X. B. Yang, J. Faghihi, and J. M. Ferris
}

First, second, and third authors: Department of Plant Pathology, Iowa State University, Ames 50011; and fourth and fifth authors: Department of Entomology, Purdue University, West Lafayette, IN 47907.

Accepted for publication 9 December 1998.

\begin{abstract}
Workneh, F., Tylka, G. L., Yang, X. B., Faghihi, J., and Ferris, J. M. 1999. Regional assessment of soybean brown stem rot, Phytophthora sojae, and Heterodera glycines using area-frame sampling: Prevalence and effects of tillage. Phytopathology 89:204-211.

The prevalence of brown stem rot (caused by Phialophora gregata), Heterodera glycines, and Phytophthora sojae in the north central United States was investigated during the fall of 1995 and 1996. Soybean fields were randomly selected using an area-frame sampling design in collaboration with the National Agricultural Statistics Service. Soil and soybean stem samples, along with tillage information, were collected from 1,462 fields in Illinois, Iowa, Minnesota, Missouri, and Ohio. An additional 275 soil samples collected from Indiana were assessed for $H$. glycines. For each field, the incidence and prevalence of brown stem rot was assessed in 20 soybean stem pieces. The prevalence and recovery (expressed as the percentage of leaf disks colonized) of $P$. sojae and the prevalence and population densities of $H$. glycines were determined from the soil samples. The prevalence of brown stem rot ranged from $28 \%$ in
\end{abstract}

ABSTRACT
Missouri to $73 \%$ in Illinois; 68 and $72 \%$ of the fields in Minnesota and Iowa, respectively, showed symptomatic samples. The incidence of brown stem rot was greater in conservation-till than in conventional-till fields in all states except Minnesota, which had few no-till fields. $P$. sojae was detected in two-thirds of the soybean fields in Ohio and Minnesota, whereas 63, 55, and $41 \%$ of the fields in Iowa, Missouri, and Illinois, respectively, were infested with the pathogen. The recovery rates of $P$. sojae were significantly greater $(P \leq 0.05)$ in conservation-till than in conventional-till fields in all states except Iowa. $H$. glycines was detected in $83 \%$ of the soybean fields in Illinois, $74 \%$ in Iowa, $71 \%$ in Missouri, 60\% in Ohio, 54\% in Minnesota, and 47\% in Indiana. Both the prevalence and population densities of $H$. glycines were consistently greater in tilled than in no-till fields in all states for which tillage information was available.

Additional keywords: bioassay, minimum-till, Phytophthora root and stem rot, soybean cyst nematode, tillage practices.
The north central United States accounts for approximately $80 \%$ of the nation's soybean production with slightly more than 22 million hectares planted with the crop (4). Soybean cultivation in this region is rapidly changing as the importance of maintenance of residue cover for soil conservation is becoming increasingly recognized. The Conservation Technology and Information Center (CTIC) now estimates that conservation tillage accounts for more than $50 \%$ of the total area under soybean production in this region, double the percentage area of a decade ago (4). In addition to increased emphasis on residue cover, the advent of drill planters has encouraged growers to adopt narrow rows for better weed control. This shift in tillage practices is expected to have a significant impact on soybean diseases in the region.

Numerous studies have described various aspects of soybean pathogens and diseases of economic importance in the north central United States (39), with primary emphases on etiology, ecology and epidemiology, and resistance. Doupnik (8) reported that diseases in this region caused estimated losses of as much as $\$ 1.3$ billion annually from 1989 to 1991 . Of the 20 soybean diseases reported to have contributed to the losses, the soybean cyst nematode (Heterodera glycines Ichinohe), Phytophthora root and

Journal paper J-17889 of the Iowa Agriculture and Home Economics Experiment Station projects 2869 and 3288 .

Corresponding author: X. B. Yang; E-mail address: xbyang@iastate.edu

Publication no. P-1999-0104-01R

(C) 1999 The American Phytopathological Society stem rot (caused by Phytophthora sojae Kaufmann \& Gerdemann), and brown stem rot (caused by Phialophora gregata (Allington \& D. W. Chamberlain) W. Gams) ranked first, second, and fifth, respectively. There is growing evidence that the three pathogens are affected by tillage practices. Population densities of $H$. glycines were reported to be greater in conventionally tilled plots than in no-till plots $(13,31)$, whereas severity levels of brown stem rot and Phytophthora root rot were greater in no-till than in conventionally tilled plots $(1,27)$.

Reliable information on the prevalence and distribution of diseases and pathogens is vital for prioritizing research needs. However, currently there is little or no such information on the prevalence of any of the major soybean diseases or pathogens in the north central United States or any other region. A few published studies in which pathogen or disease distribution were determined by systematic, experimental approaches were limited to one state $(25,26)$ or part of a state $(30)$. In most of the studies, sample siteselection processes were either arbitrary or intentionally biased toward specific objectives $(24,28,33,35)$. In some cases, the data originated from samples submitted to diagnostic clinics through extension personnel from fields suspected of having problems $(21,28)$. Data collected by these methods are not unbiased representations of the disease and pathogen situation in the areas sampled.

The present study was initiated to determine the prevalence of brown stem rot, $P$. sojae, and $H$. glycines in six states of the north central United States that account for approximately $78 \%$ of the soybean production in the region (4). The research was conducted in cooperation with the National Agricultural Statistics Service 
(NASS), which has been regularly collecting and disseminating information on various aspects of crop production, including yield estimates. Estimates on crop forecasts by NASS are unbiased and are the basis for future management decisions and marketing plans made by many farmers and agribusinesses. Other researchers have utilized similar cooperative methods of data collection with NASS to assess the prevalence of nematodes in agricultural soils $(19,25)$.

Because of the increasing use of conservation tillage practices, there is a need for unbiased assessments of tillage effects on the prevalence of the soybean pathogens. In addition, information on the prevalence of pathogens may be useful for obtaining better yield loss estimates and for directing disease-resistance breeding efforts. The primary objectives of this project were to determine the distributions of brown stem rot and the two pathogens, $P$. sojae and $H$. glycines, in six of the major soybean-producing states in the region and to assess the effects of tillage practices on their prevalence and population densities.

\section{MATERIALS AND METHODS}

Field selection. During the last several decades, NASS has been using a sampling procedure known as an area frame to arrive at unbiased estimates of aspects of crop production with measurable precision $(7,32)$. The sampling design initially includes the complete frame of the land area (a state or a region) for which estimates of crop production are desired and incorporates stratification and randomness in a multistep procedure. Initially, the land area is stratified into several categories on the basis of its use (e.g., cities, lakes, or agriculture) using a variety of map products, satellite imagery, and computer software packages. Intensively and extensively cultivated land areas fall into separate strata, enabling more weight to be given to intensively cultivated areas. Each stratum is further stratified into primary sampling units and then into segments. The segments are uniform blocks of land areas and, usually in agricultural areas, are $1.6 \mathrm{~km}^{2}$ in dimension. For crop-production estimates, NASS randomly selects these segments and, in the process, selects soybean fields by their association with the segments. For example, random samples of 435 segments are surveyed each year in Iowa to select 240 random soybean fields that represent the total soybean-production area in the state. The selected fields are the basis for crop-production estimates by NASS and served as a basis for our sample collection as well. Accordingly, during each of the 1995 and 1996 seasons, 240 fields each in Illinois and Iowa, 180 in Indiana, 120 in Minnesota, 170 in Missouri, and 160 in Ohio were identified for sample collection. During each season, soil and soybean stem samples were collected sometime between the last week of September and the first week of November.

Soil and soybean stem sampling. In each selected field, NASS establishes and maintains two yield-assessment plots, located at two randomly selected sites, from which it derives seasonal cropproduction estimates. Every year between the end of July and crop harvest, field enumerators employed by the National Association of State Departments of Agriculture visit the plots monthly to collect data on the stages of soybean growth and development. For our research, the enumerators in each state except Indiana were trained to collect soil and soybean stems in addition to their regular tasks as they walked from one yield-assessment plot to the other in each field. A liter or more of soil and 20 pieces of soybean stems were collected in a zigzag pattern from the area between the plots. The overall zigzag pattern contained 10 corners, at which the enumerators stopped and collected approximately 100 to $200 \mathrm{~cm}^{3}$ of soil and two soybean stem pieces $20 \mathrm{~cm}$ long (measured from the soil line). Soil was collected with a trowel at a depth of 0 to $20 \mathrm{~cm}$, and the soil from the 10 corners was bulked. The composite soil samples were thoroughly mixed, and approximately 1 liter of soil was subsampled. The soil and stem samples were shipped to the laboratory by second-day express mail and stored at $4{ }^{\circ} \mathrm{C}$ until they were processed. In Indiana, soil samples were collected five paces into the field beyond each of the two randomly located yield-assessment plots (each plot was $1 \mathrm{~m}$ long and two rows wide). At each plot, two samples, each $15 \mathrm{~cm}$ deep and 5 to $10 \mathrm{~cm}$ from the bases of the plants, were collected with a trowel. Approximately 1 liter of composite sample from both plots was collected and transported to Purdue University for assessment of $H$. glycines. The prevalence of brown stem rot and $P$. sojae was not assessed for the state of Indiana, and tillage information was not available.

Brown stem rot assessment. In each of the soybean stem pieces, the presence or absence of characteristic vascular and pith discoloration caused by $P$. gregata (3) was visually assessed after the stems were split longitudinally. Subsamples of stems with typical symptoms of brown stem rot and those suspected to have symptoms caused by pathogens other than $P$. gregata were kept for verification by isolation. A small segment of each stem was surface sterilized in $0.5 \% \mathrm{NaOCl}$ solution for $1 \mathrm{~min}$, and pieces of internal tissues from such stems were plated onto the semiselective medium PGM (18) and acidified potato dextrose agar. After the plated stem pieces were incubated at 22 to $24^{\circ} \mathrm{C}$, emerging fungal colonies were subcultured and examined under a microscope for typical $P$. gregata cultural characteristics and conidial shape and attachment to conidiophores. P. gregata cultures developed from stems with typical brown stem rot symptoms. However, a large proportion of the symptomatic stems from both the 1995 and 1996 Ohio samples and the 1995 Missouri samples were also colonized with other fungi, precluding visual assessment and subsequent verification of $P$. gregata by isolation. Therefore, assessments of all the Ohio samples and the 1995 Missouri samples were not included.

$\boldsymbol{P}$. sojae bioassay. Each soil sample was assayed for $P$. sojae by the leaf-disk bioassay method (20). The soil samples were taken out of cold storage and maintained at 22 to $24^{\circ} \mathrm{C}$ for 2 weeks before the bioassays were conducted. The soil was forced through a 6-mm screen to obtain uniform aggregate sizes across all samples. For the 1995 samples, the bioassay was conducted on two $60-\mathrm{cm}^{3}$ subsamples of each sample. Results of preliminary assays on selected 1996 soil samples indicated that the propagule densities of many of the samples were greater than those of the 1995 samples (data not shown). Therefore, to avoid colonization of all the leaf disks, the volume of soil used in the bioassay was reduced to $20 \mathrm{~cm}^{3}$ per subsample in 1996 . The samples were spread on top of 9-cm-deep columns of pasteurized sandy clay loam contained in $475-\mathrm{ml}$ perforated plastic cups. They were then saturated and left to drain on greenhouse benches for $96 \mathrm{~h}$. The temperature and matric potential of the samples in the cups during this period were monitored with a micrologger attached to four Watermark-200 sensors (Campbell Scientific, Logan, UT) in four additional cups containing arbitrarily selected samples set up in a similar manner. The soil temperatures in the cups ranged from 22.4 to $26.6^{\circ} \mathrm{C}$, and the matric potentials of the soil increased from 1.1 to $16.0 \mathrm{kPa}$ during the incubation period. After the incubation, the samples were flooded with distilled deionized water, and 10 soybean leaf disks $0.8 \mathrm{~cm}$ in diameter were floated on the surface of the water pooled above the soil surface. The leaf disks were obtained from young but fully unrolled leaves of the cultivar Sloan, which is susceptible to all known $P$. sojae races. After $24 \mathrm{~h}$, the leaf disks were removed and surface sterilized with $0.05 \% \mathrm{NaOCl}$ for $30 \mathrm{~s}$ and then plated onto a selective medium (five disks per $9-\mathrm{cm}-$ diameter plate) amended with $40 \mathrm{mg}$ of hymexazol per liter for inhibition of Pythium spp. (16). The plates were incubated in the dark at 22 to $24^{\circ} \mathrm{C}$, and the percentage of leaf disks colonized by $P$. sojae was determined after 4 days of incubation. Typical cultures of the isolates obtained by this process were subsequently shown to be pathogenic to susceptible soybean cultivars. Forty arbitrarily selected isolates subcultured from the leaf disks during the preliminary investigation of this project (37) were identified to races by the hypocotyl-inoculation method (40). 
H. glycines assays. Two techniques were used to assess soil samples for the presence of $H$. glycines from all the states except Indiana. A semiautomatic elutriator (5) was used to recover cysts of $H$. glycines from $100-\mathrm{cm}^{3}$ aliquots of soil from each sample. Soil was suspended in flowing water agitated by air in the elutriator. The soil suspension passed through a $250-\mu \mathrm{m}$-pore sieve on which $H$. glycines cysts, if present, were trapped. Eggs of $H$. glycines were extracted from the cysts by grinding the sediments collected on the $250-\mu \mathrm{m}$-pore sieve with a stainless steel pestle with 1-mm-deep grooves at 2,500 rpm for $60 \mathrm{~s}$ (21). Finally, eggs were recovered on a $25-\mu \mathrm{m}$-pore sieve and stained by heating the egg-sediment suspension to boiling in an acetic acid-acid fuchsin stain (21). Samples were observed and eggs counted with a dissecting microscope at $50 \times$. A sample was considered infested with $H$. glycines if one or more eggs were observed.

If sufficient soil remained in a sample following extraction with the semiautomatic elutriator, a greenhouse bioassay test was performed as a second test for $H$. glycines infestation. Soil was placed in a $250-\mathrm{cm}^{3}$-capacity container, and three seeds of the susceptible soybean cultivar Corsoy 79 were planted. Plants were thinned to one per container within 7 to 14 days after planting. After incubation at $26^{\circ} \mathrm{C}$ in a greenhouse for 28 to 35 days with a photoperiod of $16 \mathrm{~h}$ of light and $8 \mathrm{~h}$ of darkness, soil was carefully removed from the roots of the plants, and the roots were observed with the unaided eye for the presence of $H$. glycines females. If no females were detected, the roots were observed subsequently at $12 \times$ with a dissecting microscope for the presence of $H$. glycines females. A

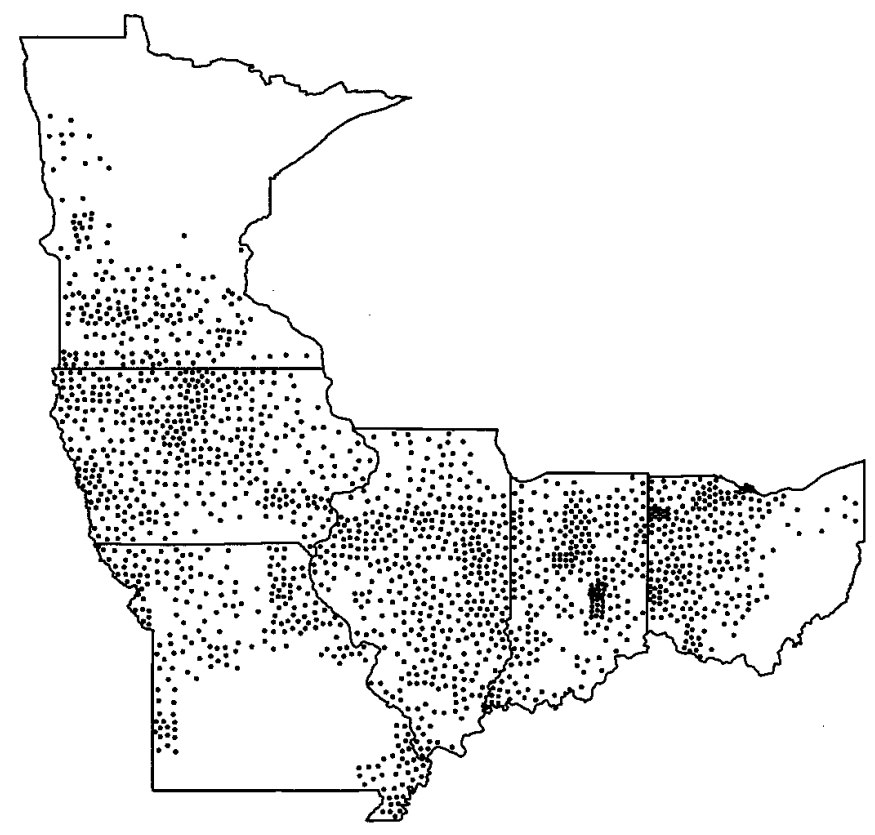

Fig. 1. Locations of randomly selected fields in Illinois, Indiana, Iowa, Minnesota, Missouri, and Ohio from which soil and soybean stem samples were collected during the fall of 1995 and 1996. Each dot represents one field. sample was designated infested with $H$. glycines if one or more females were observed on the roots of the soybean bioassay plants. If no eggs were detected in a soil sample but the bioassay was positive, the sample was considered infested with $H$. glycines.

For Indiana samples, the soil was thoroughly mixed, and $250 \mathrm{~cm}^{3}$ was suspended in water and poured through nested 710and $250-\mu \mathrm{m}$-pore sieves. The contents on the $250-\mu \mathrm{m}$-pore sieve were examined for the presence of cysts under a dissecting microscope. The cysts were subsampled and further examined under a compound microscope to determine whether they were cysts of $H$. glycines. After confirmation, they were crushed and the released eggs were counted. Soil samples in which cysts were not detected were planted to the susceptible soybean cultivar Williams 82 in $10-\mathrm{cm}$ pots and placed in the greenhouse at $24^{\circ} \mathrm{C}$ with $16 \mathrm{~h}$ of light and $8 \mathrm{~h}$ of darkness. After 6 to 8 weeks, the plants were uprooted, and the roots were examined for the presence of $\mathrm{H}$. glycines females.

Tillage system designations. Tillage systems are classified into several categories on the basis of the amount of surface residue (4). Conservation tillage systems (including no-till, mulch-till, and ridge-till) are tillage practices that maintain greater than $30 \%$ residue after planting. Tillage practices that maintain 15 to $30 \%$ residues are categorized as reduced-till or minimum-till, whereas those that maintain less than $15 \%$ residue cover are classified as conventional-till. Terms such as reduced-till, minimum-till, and mulch-till are loosely and often interchangeably used by farmers and agricultural professionals, even though there are strict definitions based primarily on the amount of surface residues. It is often difficult to distinguish the various forms of tillage practices that range between conventional-till and no-till. For our research, till-

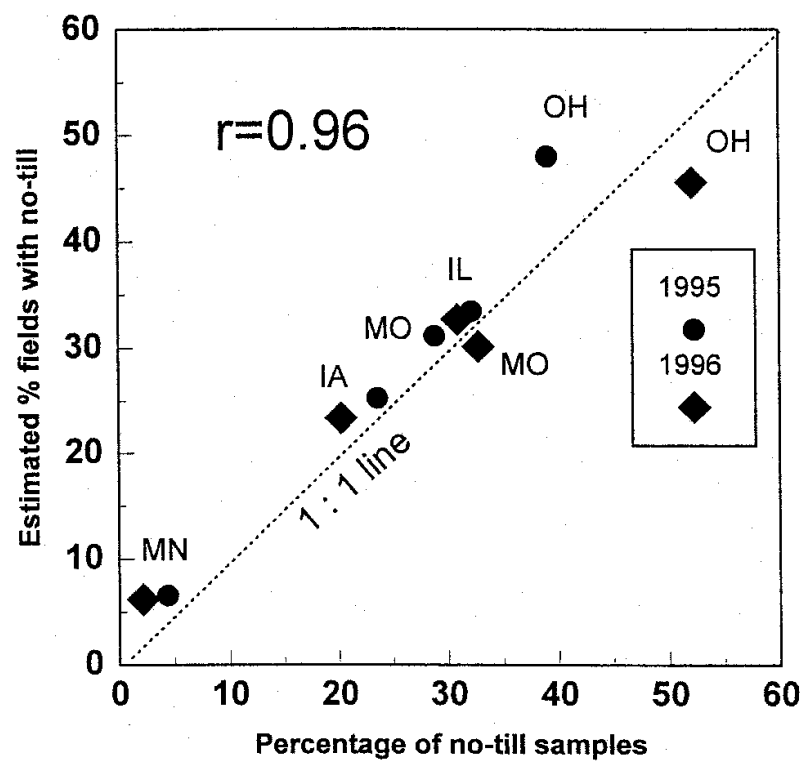

Fig. 2. Relationships between the percentage of no-till samples from each state and the estimated percentage of no-till fields in 1995 and 1996.

TABLE 1. Numbers of soil samples collected and processed from no-till (NT), minimum-till (MT), and conventional-till (CT) fields in five states of the north central United States during the fall of 1995 and $1996^{\text {a }}$

\begin{tabular}{|c|c|c|c|c|c|c|c|}
\hline \multirow[b]{2}{*}{ State } & \multicolumn{3}{|c|}{1995} & \multicolumn{3}{|c|}{1996} & \multirow[b]{2}{*}{ Total } \\
\hline & NT & MT & CT & NT & MT & $\mathrm{CT}$ & \\
\hline Illinois & $62(32)^{b}$ & $70(36)$ & $61(32)$ & $62(31)$ & $75(37)$ & $64(32)$ & 394 \\
\hline Iowa & $45(24)$ & $66(34)$ & $80(42)$ & $42(20)$ & $103(50)$ & $63(30)$ & 399 \\
\hline Minnesota & $4(4)$ & $26(28)$ & $62(68)$ & $2(2)$ & 27 (28) & $66(70)$ & 187 \\
\hline Missouri & $36(29)$ & $38(30)$ & $51(41)$ & $37(33)$ & $45(40)$ & $31(27)$ & 238 \\
\hline Ohio & $48(39)$ & $23(18)$ & $52(43)$ & $63(52)$ & $24(20)$ & $34(28)$ & 244 \\
\hline Total & 195 & 223 & 306 & 206 & 274 & 258 & 1,462 \\
\hline
\end{tabular}

a Based on the numbers of samples processed for Heterodera glycines eggs.

${ }^{\mathrm{b}}$ Numbers in parentheses are the percentages of samples per year in each state that were from the three tillage categories. 
age information for individual fields was obtained from farmers by NASS during interviews conducted before data collection. Fields that were not either conventional-till or no-till but received various degrees of tillage operations and had various amounts of surface residues ranging between that of no-till and that of conventional-till were designated minimum-till. Therefore, our categorization of tillage practices, other than conventional-till and notill, may not necessarily fit the CTIC definitions.

Data analyses. The soybean fields sampled in 1996 were different from those sampled in 1995 because of the corn-soybean rotation schemes followed in the states that were sampled. In addition, there were no interactions between year and tillage for any of the pathogen or disease assessments (data not shown). Therefore, analyses were conducted on pooled results of samples from both years as the samples were collected from randomly selected locations each year. The amounts of residue maintained on the surface of minimum-till fields are greater than those on conventional-till fields, even though there are considerable variations among fields in the amounts of residue. Since $P$. gregata and $P$. sojae have been reported to depend primarily on residues for long-term survival $(2,27)$, data from minimum-till and no-till samples were pooled and reclassified under the category "conservation-till" and compared with data from conventional-till. In contrast, since the abundance and spatial distribution of $H$. glycines are influenced more by soil disturbance associated with tillage (41) than by residues, data from minimum-till fields were grouped with data from conventional-till fields into the category "tilled" and compared with data from no-till fields.

In this paper, the term "prevalence" is used to describe the percentage of fields in a state in which the disease or the pathogen was detected and the term "incidence" is used to describe the percentage of samples from a field in which the disease or the pathogen was detected (42). The prevalence of brown stem rot, $P$. sojae, and $H$. glycines in each state was summarized by tillage category, and the differences in prevalence between the tillage categories were determined by the chi-square test. The percentage of leaf disks colonized by $P$. sojae and the percentage of stem pieces with brown stem rot were transformed by arcsine transformation, and the differences between the tillage categories were determined by Student's $t$ test. Values of $H$. glycines egg densities were transformed to logarithmic scale $\left(\log _{10}+1\right)$ and analyzed for tillage effects by Student's $t$ test. Relationships between egg densities of $H$. glycines and its prevalence and the number of years elapsed since its discovery in each state were determined with the Pearson correlation statistic. All analyses were conducted with SAS software (SAS Institute, Cary, NC).

\section{RESULTS}

During the 2 years of the study, 1,737 fields from six states were sampled (Fig. 1); of these, 1,462 samples from five states contained tillage information (Table 1). The percentage of each tillage system in the samples was similar to that estimated by the CTIC for each state (Fig. 2). For example, during the 1995 season, it was estimated that no-till soybean fields in Illinois represented $33.5 \%$ of the total soybean production in the state. In our random samples, $32 \%$ of the 193 total samples from Illinois were from notill fields.

There was wide variation among states in the prevalence of brown stem rot, $P$. sojae, and H. glycines. Soybean fields in Illinois, Iowa, and Minnesota had similar levels of brown stem rot prevalence, ranging from 68 to $73 \%$, whereas Missouri had the lowest level of disease prevalence with $28 \%$ of the fields having symptomatic samples (Table 2). P. sojae was detected in soil samples from approximately two-thirds of the soybean fields in Iowa, Minnesota, and Ohio. Illinois had the lowest prevalence of P. sojae with $41 \%$ of the fields showing a positive bioassay. Conversely, Illinois had the highest percentage of fields in which H. glycines was detected (83\%), followed by Iowa (74\%) and Missouri (71\%).

The prevalence of brown stem rot was significantly greater in conservation-till fields than in conventional-till fields in Illinois and Iowa $(P=0.001$ and 0.008 , respectively) (Table 3$)$. However, there was no significant difference in prevalence of the disease

TABLE 2. Prevalence of brown stem rot, Phytophthora sojae, and Heterodera glycines in six states of the north central United States in samples collected during the fall of 1995 and 1996

\begin{tabular}{|c|c|c|c|c|c|c|}
\hline \multirow[b]{2}{*}{ State } & \multicolumn{2}{|c|}{ Brown stem rot } & \multicolumn{2}{|c|}{ P. sojae } & \multicolumn{2}{|c|}{ H. glycines } \\
\hline & $\begin{array}{l}\text { No. of } \\
\text { fields }\end{array}$ & $\begin{array}{c}\text { Positive } \\
(\%)\end{array}$ & $\begin{array}{l}\text { No. of } \\
\text { fields }\end{array}$ & $\begin{array}{c}\text { Positive } \\
(\%)\end{array}$ & $\begin{array}{l}\text { No. of } \\
\text { fields }\end{array}$ & $\begin{array}{c}\text { Positive }^{\mathrm{a}} \\
(\%)\end{array}$ \\
\hline Illinois & 383 & 73.1 & 399 & 41.4 & 394 & 82.7 \\
\hline Indiana & $\ldots{ }^{b}$ & $\ldots$ & $\ldots$ & $\ldots$ & 275 & 46.5 \\
\hline Iowa & 365 & 72.3 & 397 & 62.9 & 399 & 74.2 \\
\hline Minnesota & 183 & 68.3 & 188 & 67.0 & 187 & 53.5 \\
\hline Missouri & $95^{\mathrm{c}}$ & 28.4 & 229 & 54.6 & 238 & 71.4 \\
\hline Ohio & $-^{c}$ & - & 231 & 68.0 & 244 & 60.3 \\
\hline
\end{tabular}

a Samples with detectable egg population densities or positive greenhouse bioassays.

${ }^{\mathrm{b}}$ Indiana samples were assessed only for $H$. glycines.

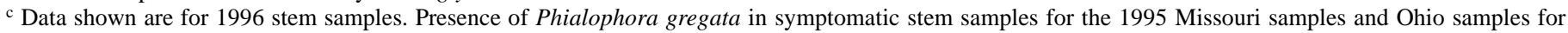
both years could not be verified by isolation because of excessive overgrowth of other fungi.

TABLE 3. Prevalence of brown stem rot (BSR) and Phytophthora sojae in samples collected from conservation-till and conventional-till fields in five states of the north central United States during the fall of 1995 and 1996

\begin{tabular}{|c|c|c|c|c|c|c|c|c|c|c|}
\hline \multirow[b]{2}{*}{ State } & \multicolumn{2}{|c|}{ Conservation-till $^{\mathrm{a}}$} & \multicolumn{2}{|c|}{ Conventional-till } & \multirow[b]{2}{*}{$P>\chi^{2}$} & \multicolumn{2}{|c|}{ Conservation-till } & \multicolumn{2}{|c|}{ Conventional-till } & \multirow[b]{2}{*}{$P>\chi^{2}$} \\
\hline & $\begin{array}{l}\text { No. of } \\
\text { fields }\end{array}$ & $\begin{array}{c}\% \text { with } \\
\text { BSR }\end{array}$ & $\begin{array}{l}\text { No. of } \\
\text { fields }\end{array}$ & $\begin{array}{c}\% \text { with } \\
\text { BSR }\end{array}$ & & $\begin{array}{l}\text { No. of } \\
\text { fields }\end{array}$ & $\begin{array}{l}\% \text { with } \\
P \text { sojae }\end{array}$ & $\begin{array}{l}\text { No. of } \\
\text { fields }\end{array}$ & $\begin{array}{l}\% \text { with } \\
P . \text { sojae }\end{array}$ & \\
\hline Illinois & 262 & 79.7 & 121 & 58.9 & 0.001 & 272 & 42.7 & 127 & 38.6 & 0.44 \\
\hline Iowa & 238 & 76.8 & 127 & 63.9 & 0.008 & 254 & 64.2 & 143 & 62.9 & 0.81 \\
\hline Minnesota & 59 & 71.2 & 124 & 66.9 & 0.56 & 60 & 76.7 & 128 & 62.5 & 0.05 \\
\hline Missouri & $72^{b}$ & 29.2 & 23 & 26.1 & 0.71 & 151 & 57.0 & 78 & 50.0 & 0.32 \\
\hline Ohio & $\ldots b^{b}$ & $\ldots$ & $\ldots$ & $\ldots$ & $\ldots$ & 152 & 71.7 & 79 & 60.8 & 0.09 \\
\hline
\end{tabular}

${ }^{a}$ Contains samples from no-till and minimum-till fields.

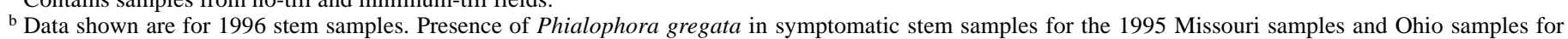
both years could not be verified by isolation because of excessive overgrowth of other fungi. 
between the two tillage categories in Minnesota and Missouri. Overall, the disease was present in more than $58 \%$ of the fields in both conservation-till and conventional-till fields in all states except Missouri, where it was detected in less than $30 \%$ of the fields.

In most of the states, there was no significant difference in prevalence of $P$. sojae between tillage systems. The exception was Minnesota $(P=0.05)$, where the pathogen was detected in $77 \%$ of the conservation-till fields and $63 \%$ of the conventional-till fields (Table 3). Overall, the percentage of fields in which $P$. sojae was detected ranged from 43 to $77 \%$ in conservation-till fields and from 39 to $63 \%$ in conventional-till fields.

The trend in effect of tillage practices on the prevalence of $H$. glycines was similar in all states surveyed (Table 4). Of the five states, $H$. glycines prevalence was greatest in Illinois; $87 \%$ of the tilled fields and $74 \%$ of no-till fields were infested. Eggs were present in more tilled fields than in no-till fields in Illinois, Iowa, Missouri, and Ohio ( $P=0.002,0.02,0.11$, and 0.04 , respectively). In Minnesota, only six no-till fields were randomly selected compared with 181 tilled fields. Thus, there were too few no-till samples to make any statistical inferences about the effects of tillage on the prevalence of $H$. glycines.

The incidence of brown stem rot was significantly greater in conservation-till fields than in conventional-till fields in Illinois and Iowa $(P=0.001$ and 0.002 , respectively). However, there was no significant difference in incidence between the tillage categories in Minnesota and Missouri (Fig. 3). In the two states in which the differences were significant, conservation-till fields had 10 to $12 \%$ greater incidence of the disease than conventional-till fields. Overall, the mean incidence of the disease per field was

TABLE 4. Prevalence of Heterodera glycines in tilled and no-till fields in five states of the north central United States sampled during the fall of 1995 and 1996

\begin{tabular}{|c|c|c|c|c|c|}
\hline \multirow[b]{2}{*}{ State } & \multicolumn{2}{|c|}{ No-till } & \multicolumn{2}{|c|}{ Tilled $^{\mathrm{a}}$} & \multirow[b]{2}{*}{$P>\chi^{2}$} \\
\hline & $\begin{array}{l}\text { No. of } \\
\text { fields }\end{array}$ & $\begin{array}{c}\% \text { with } \\
\text { H. glycines }\end{array}$ & $\begin{array}{l}\text { No. of } \\
\text { fields }\end{array}$ & $\begin{array}{c}\% \text { with } \\
\text { H. glycines }\end{array}$ & \\
\hline Illinois & 124 & 74.2 & 270 & 86.7 & 0.002 \\
\hline Iowa & 87 & 64.4 & 312 & 76.9 & 0.02 \\
\hline Minnesota & 6 & 33.3 & 181 & 54.1 & 0.32 \\
\hline Missouri & 73 & 64.4 & 165 & 74.6 & 0.11 \\
\hline Ohio & 111 & 53.2 & 133 & 66.2 & 0.04 \\
\hline
\end{tabular}

${ }^{a}$ Contains samples from conventional-till and minimum-till fields.

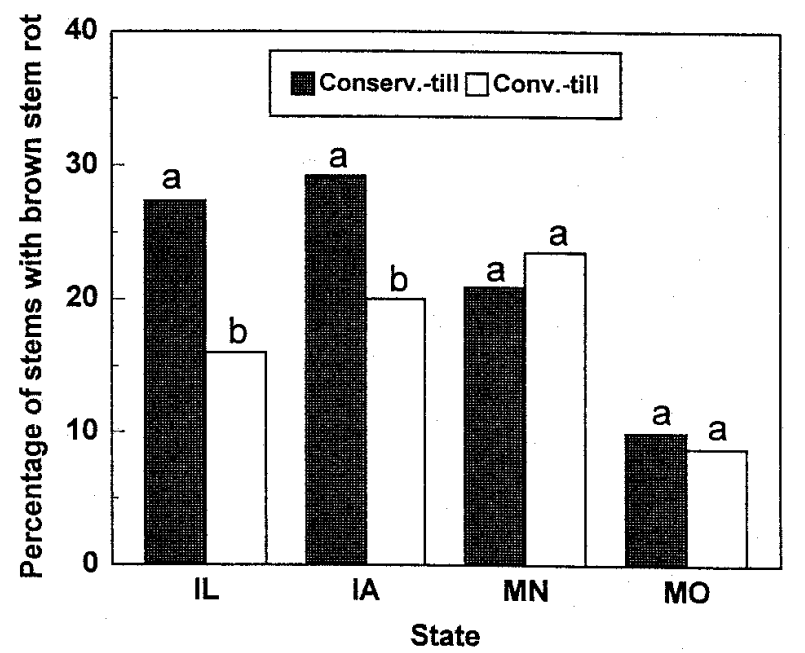

Fig. 3. Mean incidence of brown stem rot, expressed as the percentage of symptomatic stems, in conservation-till and conventional-till fields in Illinois, Iowa, Minnesota, and Missouri. Bars with the same letter within each state are not significantly different according to Student's $t$ test. less than $30 \%$ in all the states in which the disease was assessed. Missouri showed an incidence of slightly less than $10 \%$.

In all states, recovery of $P$. sojae (expressed as the percentage of leaf disks colonized) was greater in conservation-till fields than in conventional-till fields. The percentage of leaf disks colonized was significantly greater in conservation-till than in conventional-till fields in Illinois, Minnesota, Missouri, and Ohio $(P=0.04,0.05$, 0.01 , and 0.04 , respectively) but not in Iowa $(P=0.43)$ (Fig. 4).

In all states except Minnesota, $H$. glycines egg population densities were greater in tilled than in no-till fields. Overall, egg densities in tilled fields were 1.5 to 2.5 times greater than in notill fields. The differences in egg population densities between the tillage categories were significant in Illinois $(P=0.01)$, Iowa $(P=$ $0.002)$, and Ohio $(P=0.01)$ (Fig. 5). There was also a strong correlation between mean egg population densities of $H$. glycines in each state and the percentage of fields infested ( $r=0.91 ; P=$ 0.01) (Fig. 6A), indicating that prevalence was greater in states that had fields with high egg densities than in states that had fields with low egg densities. In the six states of the north central United States, the soybean cyst nematode was discovered for the first time in various years between 1956 and 1987 (22). The mean population density of $H$. glycines eggs in each state was moderately correlated with the number of years that had elapsed since it was first detected in soybean fields of that state $(r=0.74 ; P=0.1)$ (Fig. 6B).

\section{DISCUSSION}

Brown stem rot, Phytophthora root rot, and soybean cyst nematode are three of the most economically important soybean diseases in the north central United States (8). Information on how widely these pathogens are distributed is useful for making management decisions and for prioritizing research needs. In this study, we determined the prevalence of brown stem rot (caused by $P$. gregata), $P$. sojae, and $H$. glycines in five or six states in the north central United States using soil and soybean stem samples collected from randomly selected fields. We also showed how the prevalence and population densities of the pathogens were affected by tillage practices in each state. The importance of these pathogens has been described by various researchers utilizing the results of localized experiments (39). However, the present study was the first to assess the prevalence and distribution of the pathogens on a regional scale with samples derived from a large number of fields selected in an unbiased manner. The use of the areaframe sampling method provided soybean fields in every segment

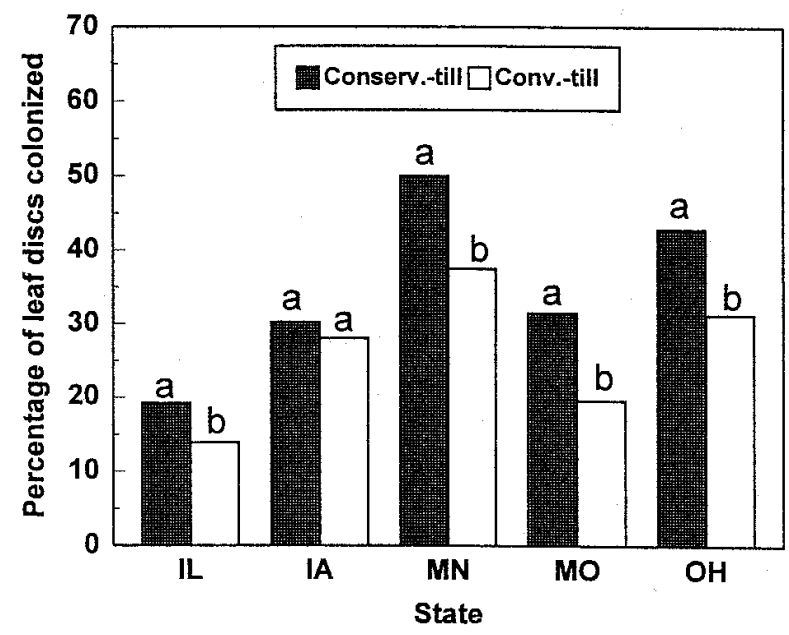

Fig. 4. Mean recovery of Phytophthora sojae, expressed as the percentage of leaf disks colonized, in conservation-till and conventional-till fields in Illinois, Iowa, Minnesota, Missouri, and Ohio. Bars with the same letter within each state are not significantly different according to Student's $t$ test. 
of the land area of each state where each field had a known probability of being selected. This sampling approach also provided highly representative fields for estimation of how widely the pathogens were distributed within the region. The sampling accuracy was evident from the fact that the percentage of our samples from each tillage system closely matched the CTIC estimated percentages of tillage systems in each state. The CTIC is an independent (separate from NASS) organization that conducts annual surveys for monitoring trends in conservation tillage practices for all crops using of the point-sampling method. The similarity between the percentages of each tillage system in our samples and estimated tillage system frequencies for each state confirmed that each tillage system was represented without bias.

Brown stem rot was detected in significantly more conservation-till fields than in conventional-till fields in Illinois and Iowa. Furthermore, the mean incidence of brown stem rot per field was significantly greater in conservation-till than in conventional-till fields in these two states. The survival of $P$. gregata in soybean stem residues is well documented $(2,12,14)$, and the survival of the fungus has been shown to be greater in surface residues than in buried residues (2) because surface residues decompose more slowly than buried residues (11). Also, Adee et al. (1) showed in a field experiment that disease severity of no-till plots is significantly greater than that of conventional-till plots. Results of our study demonstrate on a regional scale that brown stem rot incidence is greater in conservation-till than in conventional-till fields.

Because there were only six no-till samples from Minnesota compared with 52 minimum-till and 132 conventional-till samples, data from the conservation-till category comprised mostly that of minimum-till fields. No-till fields have greater residue cover than minimum-till fields and, on the basis of published reports, were expected to have greater brown stem rot incidence (1). Hence, the absence of a large number of samples from no-till fields in Minnesota may have contributed to the lack of differences in brown stem rot incidence between conservation-till and conventional-till fields. In Missouri, there was less than $10 \%$ brown stem rot incidence in both conservation-till and conventional-till fields, and the incidence may have been too low to show differences between the tillage systems. Furthermore, data from Missouri were from 1 year of samples only, and hence the sample size is small compared with that of the rest of the states.

The difference in prevalence of $P$. sojae between the tillage categories was not significant except in Minnesota, where it was greater in conservation-till than in conventional-till fields. However, the recovery of the pathogen was significantly greater in

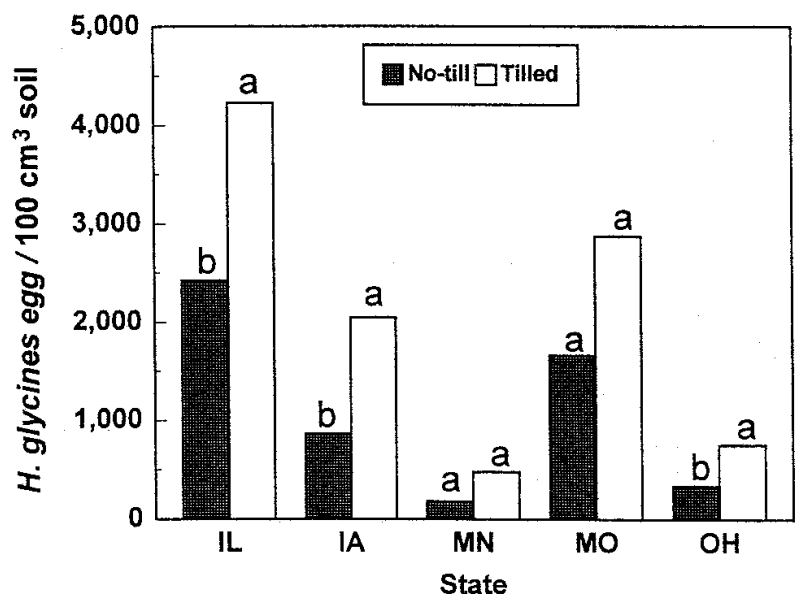

Fig. 5. Mean egg population densities of Heterodera glycines in no-till and tilled fields in Illinois, Iowa, Minnesota, Missouri, and Ohio. Bars with the same letter within each state are not significantly different according to Student's $t$ test. conservation-till than in conventional-till fields in all states except Iowa, indicating that the difference between the tillage categories may result from the level of infestation and not from the presence or absence of $P$. sojae. This finding is in agreement with recent investigations that showed that the recovery of $P$. sojae was greater in no-till than in conventional-till fields and that the amount of surface residue was positively associated with recovery of the pathogen $(37,38)$.

In most of the states, the prevalence and egg population densities of $H$. glycines were significantly greater in tilled than in notill fields. This is in agreement with earlier findings by Tyler et al. (31) and Koenning et al. (13) that $H$. glycines egg densities are greater in conventionally tilled fields than in no-till fields. Our results further indicate that soil movement associated with tillage is the primary factor in distribution of $H$. glycines and suggest that the increasing trend toward no-till practices in the north central region may counteract the effects of conventional tillage practices.

It is interesting to note that there was great variability among the states in $H$. glycines prevalence and egg densities. In addition
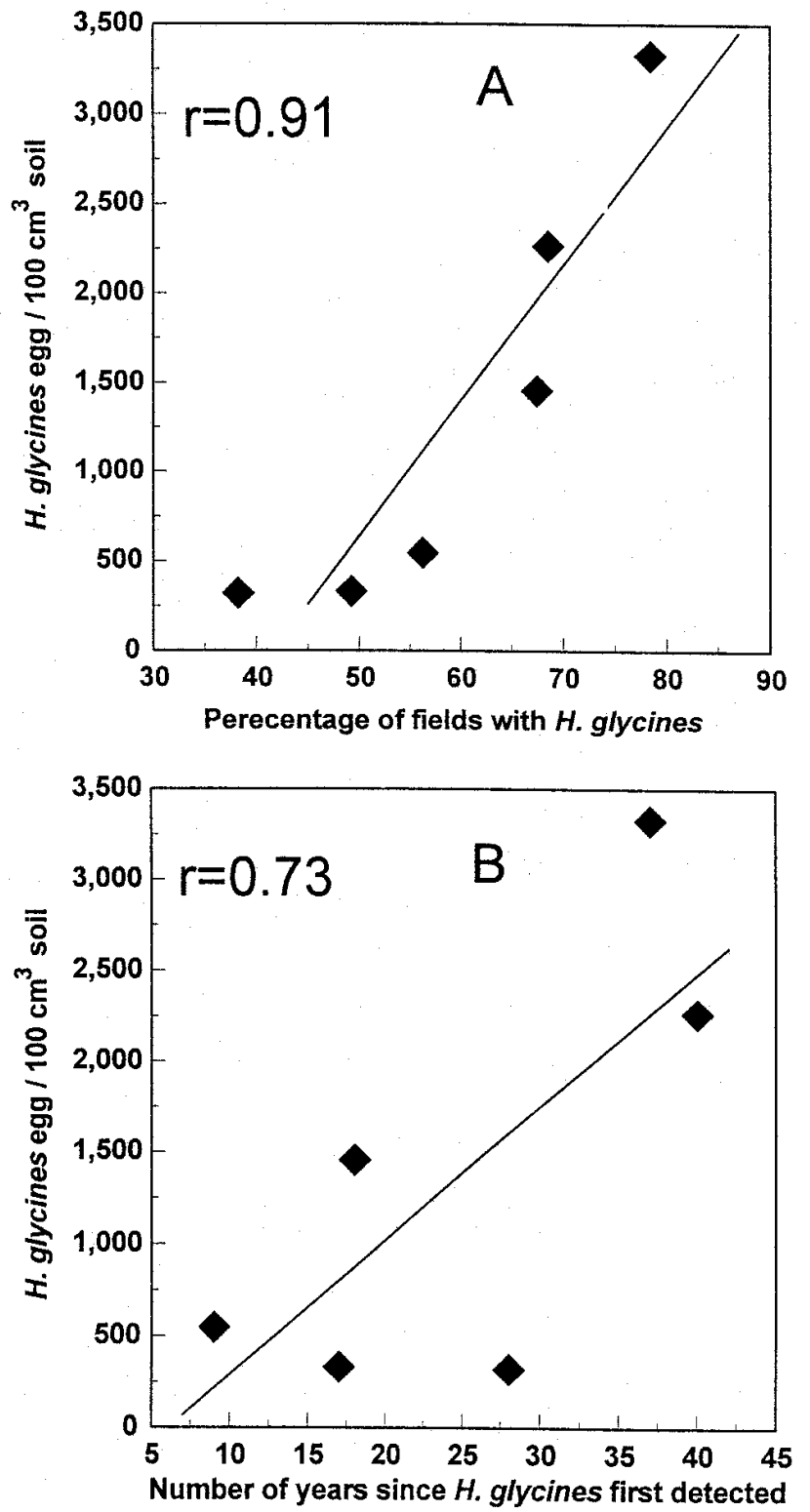

Fig. 6. A, Relationship between Heterodera glycines egg-population densities and the percentage of fields infested $(P=0.01)$. B, Relationship between $H$. glycines egg-population densities and the number of years elapsed since its discovery in each state $(P=0.1)$. 
to tillage effects, time of introduction may have significant impact on the prevalence and distribution of the nematode in individual states. It is believed that the soybean cyst nematode was introduced into the United States in the 1950s (36). In the six states of the north central United States, H. glycines was first discovered between 1956 and 1987 (22). Egg population densities in each state correlated with the number of years elapsed after first detection of the pathogen, suggesting that time is an important factor in the spread and distribution of the nematode across each state. One can conclude, therefore, that the prevalence of $H$. glycines within a given state may be partly attributable to tillage practices and to years elapsed after the introduction of the pathogen into that particular state.

Brown stem rot is favored by cool conditions $(6,10,23)$, and consequently one may expect variations in incidence of the disease between the states resulting from latitudinal positions. The fact that soybean fields in Missouri had the least prevalence may be attributed to this fact. Such latitudinal variation was evident in Illinois, where incidence of the disease was greater in the northern half of the state than in the southern half (data not shown). In addition, there are many soybean cultivars with resistance to brown stem rot $(17,29)$, and they may have been planted in the region in a nonrandom pattern. Therefore, our assessment of the prevalence of the disease in randomly selected fields may not have accounted for variations caused by differences in cultivar resistance.

It is well documented that diseases caused by Phytophthora species are affected by physical factors of the soil such as texture $(9,34)$. Saturation is generally prolonged in fields with high clay content, a condition that predisposes plants to infection by the fungus. The prevalence and recovery of $P$. sojae, therefore, may depend on soil types in addition to tillage practices. Even though the effect of tillage practices on recovery of the pathogen was consistent across the states (except Iowa), it is possible that variations caused by soil types may have interacted with the effects of the tillage practices. The relative contributions of tillage and soil type is an area that needs to be further investigated.

The degree of precision in assessing the prevalence of any pathogen or disease in a given area is strongly influenced by the methods used in sample collection and in detection of the pathogens and diseases. In this study, samples were collected from representative soybean fields that encompassed all tillage systems in each state. For assessments of brown stem rot and the two pathogens, we chose methods that are the most widely used by scientists and that are feasible for handling large numbers of samples. It is possible that $P$. gregata can be isolated from some of the apparently healthy internal parts of stems. However, the main objective of the project was to assess the disease and not the presence or the absence of the pathogen in the stems. Furthermore, isolation from the nearly 30,000 stem pieces was not feasible with our limited resources. The leaf-disk bioassay method best measures the presence or absence of an organism in a sample (15), which in this case is the prevalence of $P$. sojae. It can also be used to measure the relative abundance of an organism in different treatments. Our description of the recovery of $P$. sojae in different tillage categories from the five states, therefore, is a comparative assessment and does not determine the absolute densities of the pathogen in the soil. We used egg-population densities and greenhouse bioassay methods for assessments of $H$. glycines. Even though these methods are widely used, both have advantages and disadvantages. Use of egg-population densities may result in inclusion of false positives in the data, since there is a possibility that eggs of nematodes other than $H$. glycines can be recovered from the soil samples. Conversely, the bioassay method can yield false negative results where infection of soybean roots may fail to occur, even though viable eggs are present in the soil samples.

There are wide variations in tillage practices that are not either conventional-till or no-till that may lead to inconclusive results of tillage effects. However, meaningful results were obtained by grouping the tillage practices into categories of conventional-till and conservation-till or tilled and no-till based on the ecology of the pathogens. The six states surveyed in this study account for approximately $78 \%$ of the soybean area in the north central United States (4). The results of our investigations provide estimates of how widespread brown stem rot, $P$. sojae, and $H$. glycines are in these states. In addition, the study shows that tillage practices have a significant impact on their prevalence. Population densities of pathogens and the severity of diseases are dynamic in nature. Even though we used statistically sound assessment methods, their incidence and prevalence may change depending on weather conditions and trends in tillage practices. However, we believe that our data represent accurate assessments of the exiting conditions that may be useful in loss assessments and prioritization of research needs.

\section{ACKNOWLEDGMENTS}

This research was supported by the Iowa Soybean Promotion Board, the North Central Soybean Research Program, Hatch Act and the State of Iowa funds, and the Iowa State University Extension IPM Program. We thank H. Holden of the Iowa Department of Agriculture and Land Stewardship, Bureau of Agricultural Statistics, for coordination of soil and stem sample collection by National Association of State Departments of Agriculture enumerators and for assistance in obtaining additional data about the sample sites. We thank S. K. Souhrada, H. A. Roozen, D. H. Soh, and R. L. Edmonds for technical assistance. We also thank P. Lundeen for help in organization of the sample shipment.

\section{LITERATURE CITED}

1. Adee, E. A., Grau, C. R., and Oplinger, E. S. 1997. Population dynamics of Phialophora gregata in soybean residue. Plant Dis. 81:199-203.

2. Adee, E. A., Oplinger, E. S., and Grau, C. R. 1994. Tillage, rotation sequence, and cultivar influences on brown stem rot and soybean yield. J. Prod. Agric. 7:341-347.

3. Allington, W. B., and Chamberlain, D. W. 1948. Brown stem rot of soybean. Phytopathology 38:793-802.

4. Anonymous. 1997. Crop Residue Management: Midwest Region. Conservation Technology and Information Center, West Lafayette, IN.

5. Byrd, D. W., Barker, K. R., Jr., Ferris, H., Nusbaum, C. J., Griffen, W. E., Small, H. R., and Stone, C. A. 1976. Two semi-automatic elutriators for extracting nematodes and certain fungi from soil. J. Nematol. 8:206-212.

6. Chamberlain, D. W., and McAlister, D. F. 1954. Factors affecting the development of brown stem rot of soybean. Phytopathology 44:4-6.

7. Cotter, J., and Nealon, J. 1987. Area frame design for agricultural surveys. U.S. Dep. Agric. Natl. Agric. Stat. Serv. Publ. 1308.

8. Doupnik, B., Jr. 1993. Soybean production and disease loss estimates for north central United States from 1989 to 1991. Plant Dis. 77:1170-1171.

9. Duniway, J. M. 1983. Role of physical factors in the development of Phytophthora diseases. Pages 175-187 in: Phytophthora: Its Biology, Taxonomy, Ecology, and Pathology. D. C. Erwin, S. Bartincki-Garcia, and P. H. Tsao, eds. American Phytopathological Society, St. Paul, MN.

10. Dunleavy, J. 1966. Factors influencing spread of brown stem rot of soybeans. Phytopathology 56:298-300.

11. Ghidey, F., and Alberts, E. E. 1993. Residue type and placement effects on decomposition: Field study and model evaluation. Trans. ASAE 36:1611-1617.

12. Gray, L. E. 1972. Recovery of Cephalosporium gregatum from soybean straw. Phytopathology 62:1362-1364.

13. Koenning, S. R., Schmitt, D. P., Barker, K. R., and Gumpertz, M. L. 1995. Impact of crop rotation and tillage system on Heterodera glycines population density and soybean yield. Plant Dis. 79:282-286.

14. Lai, P. Y. 1968. Isolation of Cephalosporium gregatum from soybean straw. Phytopathology 58:1194-1195.

15. Larkin, R. P., Ristaino, J. B., and Campbell, C. L. 1995. Detection and quantification of Phytophthora capsici in soil. Phytopathology 85:10571063.

16. Masago, H., Yoshikawa, M., Fukuda, M., and Nakanishi, M. 1977. Selective inhibition of Pythium spp. on a medium for direct isolation of Phytophthora spp. from soils and plants. Phytopathology 67:425-428.

17. Mengistu, A., Grau, C. R., and Gritton, E. T. 1986. Comparison of soybean genotypes for resistance to and agronomic performance in the presence of brown stem rot. Plant Dis. 70:1095-1098. 
18. Mengistu, A., Tachibana, H., and Grau, C. R. 1991. Selective medium for isolation and enumeration of Phialophora gregata from soybean straw and soil. Plant. Dis. 75:196-199.

19. Neher, D. A., and Campbell, C. L. 1996. Sampling for regional monitoring of nematode communities in agricultural soils. J. Nematol. 28:196-208.

20. Neher, D. A., McKeen, C. D., and Duniway, J. M. 1993. Relationships among Phytophthora root rot development, $P$. parasitica populations in soil, and yield of tomatoes under commercial field conditions. Plant Dis. 77:1106-1111.

21. Niblack, T. L., Heinz, R. D., Smith, G. S., and Donald, P. A. 1993. Distribution, density, and diversity of Heterodera glycines in Missouri. J. Nematol. 25(suppl. 4):880-886.

22. Noel, G. R. 1992. History, distribution, and economics. Pages 1-13 in: Biology and Management of the Soybean Cyst Nematode. R. D. Riggs and J. A. Wrather, eds. American Phytopathological Society, St. Paul, MN.

23. Phillips, D. V. 1971. Influence of air temperature on brown stem rot of soybean. Phytopathology 61:1205-1208.

24. Powers, T. O., Sandall, L. J., and Wysong, D. S. 1989. Distribution of soybean cyst nematode in Nebraska. J. Nematol. 21(suppl. 4):612-614

25. Robbins, R. T., Riggs, R. D., and Von Steen, D. 1987. Results of annual phytoparasitic nematode surveys of Arkansas soybean fields, 19781986. Ann. Appl. Nematol. 1:50-55.

26. Schmitt, D. P., and Barker, K. R. 1988. Incidence of plant-parasitic nematodes in the coastal plain of North Carolina. Plant Dis. 72:107-110.

27. Schmitthenner, A. F. 1985. Problems and progress in control of Phytophthora root rot of soybean. Plant Dis. 69:362-368.

28. Sikora, E. J., and Noel, G. R. 1991. Distribution of Heterodera glycines races in Illinois. J. Nematol. 23(suppl. 4):624-628.

29. Tachibana, H. 1982. Prescribed resistant cultivars for controlling brown stem rot of soybean and managing resistance genes. Plant Dis. 66:271-274.

30. Tachibana, H., and Booth, G. D. 1979. An efficient and objective survey method for brown stem rot of soybeans. Plant Dis. Rep. 63:539-541.

31. Tyler, D. D., Chambers, A. Y., and Young, D. L. 1987. No-tillage effects on population dynamics of soybean cyst nematode. Agron. J. 79:799-802.

32. United States Department of Agriculture. 1983. Scope and methods of statistical reporting service. U.S. Dep. Agric. Misc. Publ. 1308.

33. Warner, F., Mather, R., Bird, G., and Davenport, J. 1994. Nematodes in Michigan. I. Distribution of Heterodera glycines and other plant parasitic nematodes in soybean. J. Nematol. 26(suppl. 4):720-726.

34. Weste, G. 1983. Population dynamics and survival of Phytophthora. Pages 237-257 in: Phytophthora: Its Biology, Taxonomy, Ecology, and Pathology. D. C. Erwin, S. Bartincki-Garcia, and P. H. Tsao, eds. American Phytopathological Society, St. Paul, MN.

35. Wilson, H. R., Riedel, R. M., Eisley, J. B., Young, C. E., Jasinsky, J. R. Wheeler, T. A., Kaufman, P. H., Pierson, P. E., and Stewart, M. C. 1996. Distribution of Heterodera glycines in Ohio. J. Nematol. 28(Suppl. 4): 599-603.

36. Winstead, N. N., Scotland, C. B., and Sasser, J. N. 1955. Soybean cyst nematode in North Carolina. Plant Dis. Rep. 39:9-11.

37. Workneh, F., Tylka, G. L., and Yang, X. B. 1995. Assessment of tillage effects on three soilborne pathogens in Iowa utilizing random sampling of soybean fields. (Abstr.) Phytopathology 85:1193.

38. Workneh, F., Yang, X. B., and Tylka, G. L. 1998. Effect of tillage practices on vertical distribution of Phytophthora sojae. Plant Dis. 82:1258-1263.

39. Wyllie, T. D., and Scott, D. H. 1988. Soybean Diseases of the North Central Region. American Phytopathological Society, St. Paul, MN.

40. Yang, X. B., Ruff, R. L., Meng, X. Q., and Workneh, F. 1996. Races of Phytophthora sojae in Iowa soybean fields. Plant Dis. 80:1418-1420.

41. Young, L. D. 1987. Effects of soil disturbance on reproduction of Heterodera glycines. J. Nematol. 19:141-142.

42. Zadoks, J. C., and Schein, R. C. 1979. Epidemiology of Plant Disease Management. Oxford University Press, Oxford. 